\title{
逐次型Bayes法による方向波スペクトルのオンライン推定
}

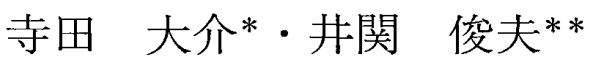

\section{Online Estimation of Directional Wave Spectra Based on Recursive Bayesian Modeling}

\author{
Daisuke TERADA and Toshio ISEKI
}

\begin{abstract}
The ship motions in waves are regarded as a nonstationary random process because of the ship maneuvers, such as changes of the course and the speed, even on the assumption that the seaway can be considered as stationary stochastic process. In this paper, the recursive type of Bayesian modeling procedure is proposed and applied to online estimation of directional wave spectra based on ship motion data, which are pitch angle, roll angle and vertical acceleration. In the proposed method, the convergence of the estimates is not achieved every time step, but gradually achieved with time steps by using the ship motion cross spectra. To cope with the nonstationarity included in the time history data, instantaneous cross spectrum analysis based on T-VVAR (Time Varying Coefficient Vector Auto Regressive) modeling procedure is adopted. The T-VVAR model is transformed into the state space model and the time varying coefficients can be evaluated by using the Kalman Filter algorithm. Using the estimated time varying coefficients, the instantaneous ship motion cross spectra can be calculated every moment. Moreover, in order to estimate the directional wave spectra stably, a new constraint condition, which is based on the observed significant wave height data, is introduced into the Bayesian modeling procedure. To examine the reliability of the proposed procedure, onboard tests were carried out on nonstationary conditions. It is shown that the statistical values derived by integration of the estimated directional wave spectra agree well with the observed one.
\end{abstract}

Key words : seakeeping qualities, directional wave spectra, recursive type of Bayesian modeling, online estimation and nonstationary time series analysis

キーワード：耐航性, 方向波スペクトル, 遂次型Bayes法, オンラインデータ処理, 非定常時系列解析

\section{1. 緒言}

船体縦曲げ応力および積載貨物の動的応答などの 統計的予測を直接計測に因らず行うことができれ ば、船舶の安全運航ならびに経済性という観点から 非常に有益である。このような理由から、著者らは 船体応答の統計的予测機能を備之た船載型安全運航 支援システムの開発を試みている(1)。このシステム において、船体応答の短期予測は、船舶が航行する
海域の方向波スペクトルと船体応答の応答関数を入 力として与えることによって行う。ここで、これら の入力は耐航性理論㧍よび著者らの最近の研究成果 を利用することによりあらかじめ推定しておくこと が可能である。すなわち、船体応答の応答関数は理 論計算 (N.S.M) から推定され、万向波スペクトル はBayes法を用いて船体動摇デー夕の周波数応答と 船体動摇の応答関数から逆推定される(2),(3)。した がって、このシステムにおいては船体応答の応答関

\footnotetext{
* 学生会員 東京商船大学大学院（广135-8533 東京都江東区越中島2-1-6)

**正 会 員 東京商船大学（T135-8533 東京都江束区越中島2-1-6)
} 
数および方向波スペクトルの推定精度が重要であ る。

ところで、方向波スペクトルを逆推定する過程に おいては、船体応答が波浪入打に対して線形であり、 かつ船体応答ならびに波浪の時系列が弱定常確率過 程であると仮定している。しかしながら、船体応答 が弱定常確率過程に従うという仮定に関しては、変 針操船などの船舶運航上の理由により成り立たない 場合が少なからず生じる。そこで、著者らはこの問 題に刘応するために、地震波解析に刘して有効性が 示された時変係数多変量自己回帰モデルによる瞬間 クロススペクトル解析 ${ }^{(4)}$ の手法を導入・拡張し、非 定常時系列解析のオンライン化を図った ${ }^{(5),(6)}$ 。その 結果、非定常性を含んだ船体応答の時系列を時間領 域および周波数領域において解析することが可能と なった。さらに、これらの研究成果を利用すること によって、方向波スペクトルをオンラインで推定す ることが可能である。著者らは、長波頂不規則波中 において波との出会い角が変化する波高計アレイの シミュレーション数值実験を行い、瞬間クロススペ クトル解析の結果に基づいて逐次型Bayes法による 方向波スペクトルのオンライン推定法の有効性を確 認した(7)。

そこで、本研究においては、安全運航支援システ ムの開発を目的として逐次型Bayes法を拡張・改良 し、実海域の方向波スペクトルを船体動摇データの みから逆推定することを試みた。具体的には、pitch 角、roll角就よび船体上下加速度のデータの瞬間ク ロススペクトルおよびそのときの船速に対応する船 体動摇応答関数を使用して方向波スペクトルを逆推 定した。また、有義波高の過大な推定を抑えること を目的として、推定計算には有義波高が目視観測結 果に一致するという制約条件式を付加した。変針時 の非定常性を含んだ時系列デー夕による方向波スぺ クトルの推定計算を行った結果から、逐次型Bayes 法の有效性が確認されたので報告するとともに、若 干の問題点についても述べる。

\section{2. 時変係数多変量自己回帰 $(T-V V A R) モ$ デルによる瞬間クロススペクトル解析}

時変係数多変量自己回帰 (T-VVAR) モデルによ る瞬間クロススペクトル解析については参考文献 (5)、(6)および(7)に詳細が記されているので、ここで はその概略について記す。

非定常な $k$ 変量時系列 $\mathbf{y}(n)$ に対するT-VVAR モデルは、自己回帰次数を $p$ として次のように表さ れる。

$$
\mathbf{y}(n)=\mathbf{D}(n) \mathbf{y}(n)+\sum_{l=1}^{p} \mathbf{B}_{l}(n) \mathbf{y}(n-l)+\varepsilon(n)
$$

ただし、 $\varepsilon(n)$ は平均值 0 、分散共分散行列 $\mathbf{Q}$ の $k$ 変 量正替分布に従う白色雑音である。また、 $\mathbf{D}(n)$ と $\mathrm{B}_{l}(n)$ は時刻 $n$ における未知の同時応答行列と係 数行列である。

自己回帰過程におけるスペクトルの定義に従え ば、瞬間クロススペクトルのマトリックスは次のよ うに表される。

$$
\begin{aligned}
& \mathbf{P}(f, n)=\mathbf{A}(f, n)^{-1} \Sigma(n) \mathbf{A}^{*}(f, n)^{-\mathrm{T}} \\
& -\frac{1}{2 \Delta t} \leq f \leq \frac{1}{2 \Delta t}
\end{aligned}
$$

ここで、記号Tは転㯰ベクトル、記号 $(-1)$ は逆行列 であることを意味している。 $\mathbf{A}(f, n)$ は次のように 定義される $\mathrm{A}_{l}(n)$ のフーリ工変換であり、

$$
\begin{aligned}
& \mathbf{A}_{l}(n)=(\mathbf{I}-\mathbf{D}(n))^{-1} \mathbf{B}_{l}(n),(l=1,2, \cdots, p), \\
& \Sigma(n)=(\mathbf{I}-\mathbf{D}(n))^{-1} \mathbf{Q}(\mathbf{I}-\mathbf{D}(n))^{-\mathrm{T}} \\
& \mathbf{A}_{0}(n)=-\mathbf{I}
\end{aligned}
$$

として、

$$
\mathbf{A}(f, n)=\sum_{l=0}^{P} \mathbf{A}_{l}(n) e^{-2 \pi i f l}
$$

で計算される。

未知のT-VVAR係数は、係数が時間に対して滑ら かに変化するという平滑化事前分布とT-VVARモ デルから状態空間モデルを構成し、Kalmanフィル タのアルゴリズムを利用して推定される。

なお、本研究においても参考文献(5)、(6)および(7) と同様、トレンドモデルおよび時変分散モデルを導 入し、計測された時系列データの規格化を行ってい る。

\section{3. 逐次型Bayes法による方向波スペクト ルの推定}

逐次型Bayes法による計算手順は既に詳しく述べ られている(7)ので、ここでは本研究において拡張し た点について述べる。具体的には、船体動摇デー夕 の瞬間クロススペクトルおよびそのときの船速に対 応する船体動摇応答関数を用いて方向波スぺクトル を逆推定する手法について述べる。さらに、逐次型 Bayes法の概略についても述べる。

船体動摇が波浪入力に対して線形応答であると仮 定すると、ある波の出会い周波数 $f_{e}$ における方向波 スペクトル $E\left(f_{e}, x\right)$ と船体動摇のクロススペクト ラム $\phi_{m n}\left(f_{e}\right)$ との関係は、一般に次のような式で表 される。 


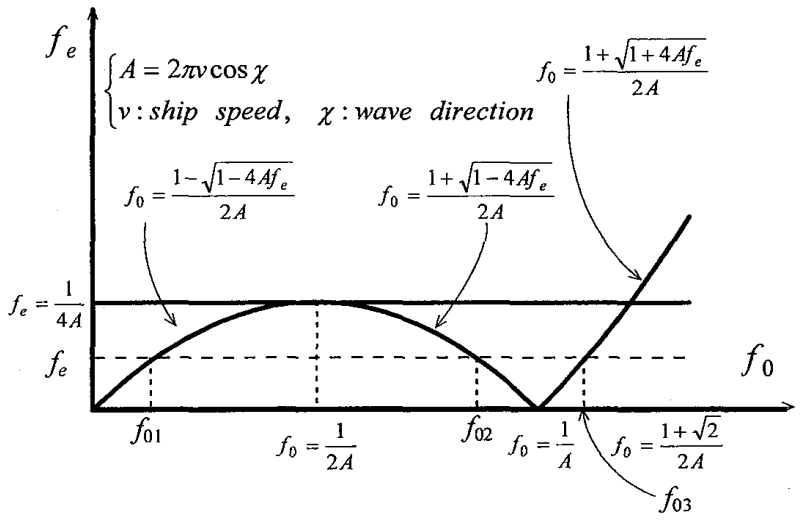

Fig. 1. The relationship between encounter wave frequencies and true wave frequencies

$$
\phi_{m n}\left(f_{e}\right)=\int_{-\pi}^{\pi} H_{m}\left(f_{e}, \chi\right) H_{n}^{*}\left(f_{e}, \chi\right) E\left(f_{e}, \chi\right) d \chi
$$

ここで、 $m$ と $n$ は船体動摇の要素を表し、 $H_{m}\left(f_{e}, \chi\right)$ 抢よび $H_{n}^{*}\left(f_{e}, \chi\right)$ はそれぞれの動摇要素の応答関 数を表す。また、 $\chi$ は波との出会い角を表している。

(4) 式は出会い周波数ベースで表されているので、 絶対周波数ベースに変換して解析を行う必要があ る。しかしながら、追い波中を航行している場合に おいて波の出会い周波数と絶対周波数がFig. 1に示 すように一対一に対応しないため、参考文献(7)に示 した手法をそのまま適用することができない。そこ で、追い波に対応する項を付加して(4) 式を変換し、 出会い角で離散化すれば、次式のようにマトリック ス表示で表される。

$$
\begin{aligned}
\boldsymbol{\Phi}\left(f_{e}\right) & =\mathbf{H}\left(f_{01}\right) \mathbf{E}\left(f_{01}\right) \mathbf{H}\left(f_{01}\right) * \mathrm{~T} \\
& +\mathbf{H}\left(f_{02}\right) \mathbf{E}\left(f_{02}\right) \mathbf{H}\left(f_{02}\right) * \mathrm{~T} \\
& +\mathbf{H}\left(f_{03}\right) \mathbf{E}\left(f_{03}\right) \mathbf{H}\left(f_{03}\right) * \mathrm{~T}
\end{aligned}
$$

ただし、 $f_{01} 、 f_{02}$ 抢よび $f_{03}$ は波との出会い周波数に対

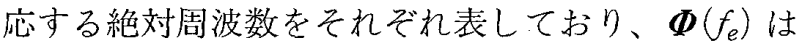
クロススペクトル行列、 $\mathbf{H}\left(f_{0 i}\right) 、 \mathbf{E}\left(f_{0 i}\right) \quad(i=1,2,3)$ はそれぞれ絶対周波数 $f_{01} 、 f_{02}$ および $f_{03}$ に対応する 船体動摇の応答関数行列㧍よび方向スペクトルを表 す行列である。

さらに、クロススペクトル行列 $\boldsymbol{\Phi}\left(f_{e}\right)$ の性質を利 用することによって、(5) 式は次式のような線形回帰 モデルで表すことができる。

$$
\mathbf{B}=\mathbf{A} F(\mathbf{x})+\mathbf{W}
$$

ただし、Bは計測した船体動摇データのクロスス ペクトルで構成されるベクトル、Aは船体動摇の応 答関数の理論值で構成される係数マトリックス、W は問題を統計的に取り扱うために導入されたホワイ トノイズおよび $F(\mathbf{x})$ は離散化された方向波スペク
トルから構成される未知べクトルを表す。

未知べクトルxを推定するために、事前分布と (6) 式で構成される次の評価関数を最小化する。

$$
J(\mathbf{x})=\|\mathbf{A} F(\mathbf{x})-\mathbf{B}\|^{2}+u^{2}\|\mathbf{D} \mathbf{x}\|^{2}
$$

ここで、Dは事前分布を表すマトリックス、 $u^{2}$ は ハイパーパラメータと呼ばれるものでありモデルの 適合度と事前分布で与えられた性質のバランスを決 める重み係数、\|・怆べクトルのノルムをそれぞれ 表す。この場合において、スペクトルは非負である ので $F(\mathbf{x})$ の各要素を次のように指数関数表示する 必要がある。

$$
F(\mathbf{x})^{\mathrm{T}}=\left(\exp \left(x_{1}\right) \cdots \exp \left(x_{\mathrm{J}}\right)\right)
$$

この未知ベクトルの置き換えを行うことにより、(7) 式のノルム内が非線形方程式となる。そこで、右辺 第 1 項の $F(\mathbf{x})$ を $\mathbf{x}_{0}$ のまわりでTaylor 展開すれ ば、実際に解く式が次のように得られる。

$$
J(\mathbf{x}) \simeq\|\hat{\mathbf{A}} \mathbf{x}-\hat{\mathbf{B}}\|^{2}+u^{2}\|\mathbf{D} \mathbf{x}\|^{2}=\left\|\left(\begin{array}{l}
\hat{\mathbf{A}} \\
u \mathbf{D}
\end{array}\right) \mathbf{x}-\left(\begin{array}{l}
\hat{\mathbf{B}} \\
0
\end{array}\right)\right\|^{2}
$$

ただし、

$$
\begin{aligned}
& \hat{\mathbf{A}}=\mathbf{A} E\left(\mathbf{x}_{0}\right), \quad \hat{\mathbf{B}}=\mathbf{B}-\mathbf{A} F\left(\mathbf{x}_{0}\right)+\hat{\mathbf{A}} \mathbf{x}_{0}, \\
& E(\mathbf{x}) \equiv \frac{\partial F(\mathbf{x})}{\partial \mathbf{x}}
\end{aligned}
$$

従来のBayes法では、適当な初期值 $\mathbf{x}_{0}$ を与え、(8) 式 を最小二乗法によって解き、得られた $\mathbf{x}$ を新しい $\mathbf{x}_{\mathbf{0}}$ として繰り返し計算を行い、収束した $\mathbf{x}$ の值を(8) 式を最小化する推定值としている。その後、反復計 算を行うことにより（8)式の中に含まれるハイパー パラメー夕 $u^{2}$ の最適值を $A B I C$ (赤池のベイズ型情 報量基準)の最小化により客観的に決定している。 したがって、従来の方法では反復計算を二重に行う ことになるため、膨大な計算量を要する。そこで、 逐次型Bayes法においては、Fig. 2のフローチャート に示すように、非線形方程式を解く場合に限定して 反復計算を実施し、(8) 式の中に含まれるハイパーパ ラメータ $u^{2}$ を各時間ステップに扔いて 2 分木探索 法 ${ }^{(8)} 1$ 回用いて決定している。

\section{4. 安定した方向波スペクトルを推定する ための計算技法}

Bayes法による方向波スペクトルの推定におい て、精度の良い推定を行うためにはピッチ角、ロー ル角拉よび波高計デー夕を使用することが望ましい ことが明らかにされている(3)。しかしながら、実際に 波高計を装備している商船は少ない。そこで、本研 


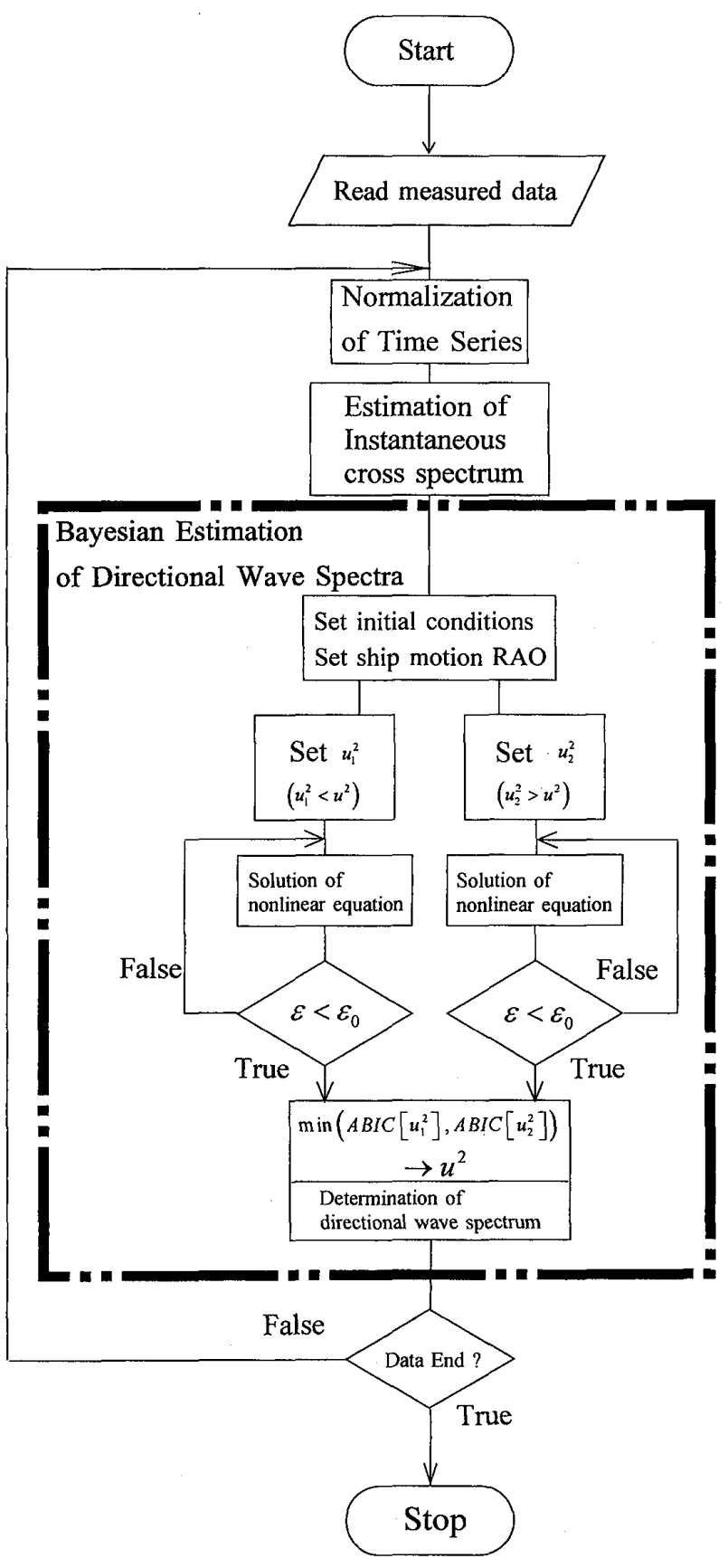

Fig. 2. Flow chart of estimating calculation

究においては、動摇計測装置のみから入手できる データすなわちピッチ角、ロール角および船体上下 加速度のデー夕を使用することとした。この場合、 参考文献(3)においても指摘されているように、方向 波スペクトルの推定精度は波高計データの使用によ る推定結果および目視観測の結果と比較して恶くな る。また、方向波スペクトルを逐次推定する場合に 扔いて、時系列デー夕が非定常になる場合に推定計 算が不安定あるいは不可能になることが生じた。

これらの問題点を解決するために、本研究では新 しく次のような制約条件を(7)式中の既知のべクト ルB拉よび係数マトリックス $\mathbf{A} に$ 付加した。

$$
H_{1 / 3}=4.0 \sqrt{\Delta f \Delta \chi \sum_{i=1}^{F_{0}} \sum_{j=1}^{K_{0}} x_{i j}}
$$

ただし、 $H_{1 / 3}$ は目視観測により得た有義波高、 $\Delta f \Delta \chi$ は面積要素、 $F_{0}$ は周波数分割数、 $K_{0}$ は方向分割数扔 よび $x_{i j}$ は方向波スペクトルをそれぞれ表してい る。

これは、推定した方向波スペクトルを積分するこ とによって得た有義波高と目視観測によって得た有 義波高が等しいという条件を表している。ゆえに、 この条件式を追加することによって、安定した方向 波スペクトルの推定が可能になるとともに目視観測 結果と同程度の有義波高を推定することが可能とな る。

\section{5.実船実験データを用いた推定計算結果 に基づく検討}

導入した手法の妥当性を検討するために、実船実 験デー夕による方向波スペクトルの推定計算を行っ た。実際の計測・計算システムはオンライン用となっ ている。しかしながら、本報告においては推定精度 の定量的・定性的な把握のため、収録した時系列デー 夕に対してオフラインで推定計算を行うこととし た。使用したデー夕は、平成13年 3 月に実施された 東京商船大学付属練習船「汐路丸」の実験航海時に 収録されたものである。デー夕は、船体中央から前 万 $8.6(\mathrm{~m})$ 、左舫側 $0.6(\mathrm{~m})$ の位置に設置された(侏)日 本航空電子製光ファイバージャイロ JCS7401GAに よって、サンプリング周期0.5秒で計測されている。 実験は波との出会い角の変化による船体動摇の変化 を計測するために、6 分間の直進航走(以降、「case1」 と表す。)、150度の变針、さらに 6 分間の直進航走(以 降、「case2」と表す。）を行った。この時のデータ点 数は2,060である。デー夕収録時の実験海域ならびに 航跡をFig. 3に示すとともに諸条件をTable 1に示 す。

Fig. 4に推定計算に使用した時系列デー夕、計測 した時系列データのトレンド成分および時変標準偏 差を示す。これらは、上から順に縦摇れ角、横摇れ 角および上下加速度であり、case1およびcase2の定 常と考えられるデータとその間の変針時における非 定常なデー夕から構成されている。この図から直進 時と変針時ならびに波との出会い角に対する船体動 摇の変化が良く表されていることが分かる。

本報告では、定常および非定常な状態が混在する 時系列デ一夕に対して、非定常性の影響を正確に取 ク入れることを目的としてT-VVARモデルによる 


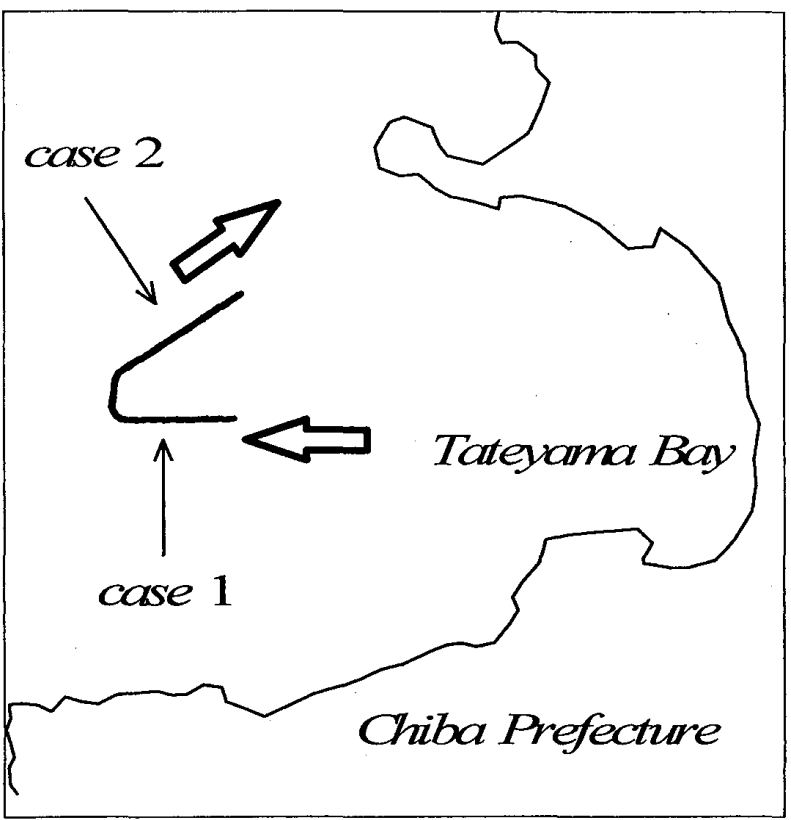

Fig. 3. Location of experimental area and trajectory

Table 1. Observed encounter wave conditions

\begin{tabular}{|l|c|c|}
\hline & case 1 & case 2 \\
\hline Ship Speed & $8.5(\mathrm{knot})$ & $9.5(\mathrm{knot})$ \\
\hline Ship Course & 270 (degree) & $60($ degree) \\
\hline $\begin{array}{l}\text { Observed Wave Direction } \\
\text { (ITTC coordinate system) }\end{array}$ & $145($ degree) & $10($ degree) \\
\hline Observed Wave Period & $7(\mathrm{sec})$ & $7(\mathrm{sec})$ \\
\hline Observed Wave Height & $1.6(\mathrm{~m})$ & $1.3(\mathrm{~m})$ \\
\hline
\end{tabular}

瞬間クロススペクトル解析を行い、得られた瞬間ク ロススペクトルに基づいて逐次型Bayes法によるう 向波スペクトルのオンライン推定を行った結果を示 亦。

\subsection{T-VVARモデルによる瞬間クロススペクト ルの推定}

Fig. 5(a)から (c) は、Fig. 4の時系列デー夕に対し て瞬間クロススペクトル解析を施した結果の一例を 示して扔り、各動摇データのオートスペクトルであ る。これらの図は、奥行き方向を時間軸として、時々 刻々推定されるスペクトルを 3 次元的に示してい る。これらの図から、時系列データのスペクトル構 造の変化が良く表されていることが分かる。すなお ち、横摇れ角についてはスペクトルのピークが変針 時に生じており、これはFig. 4の時系列における変 針時の動摇振幅が大きくなっている部分とよく対応
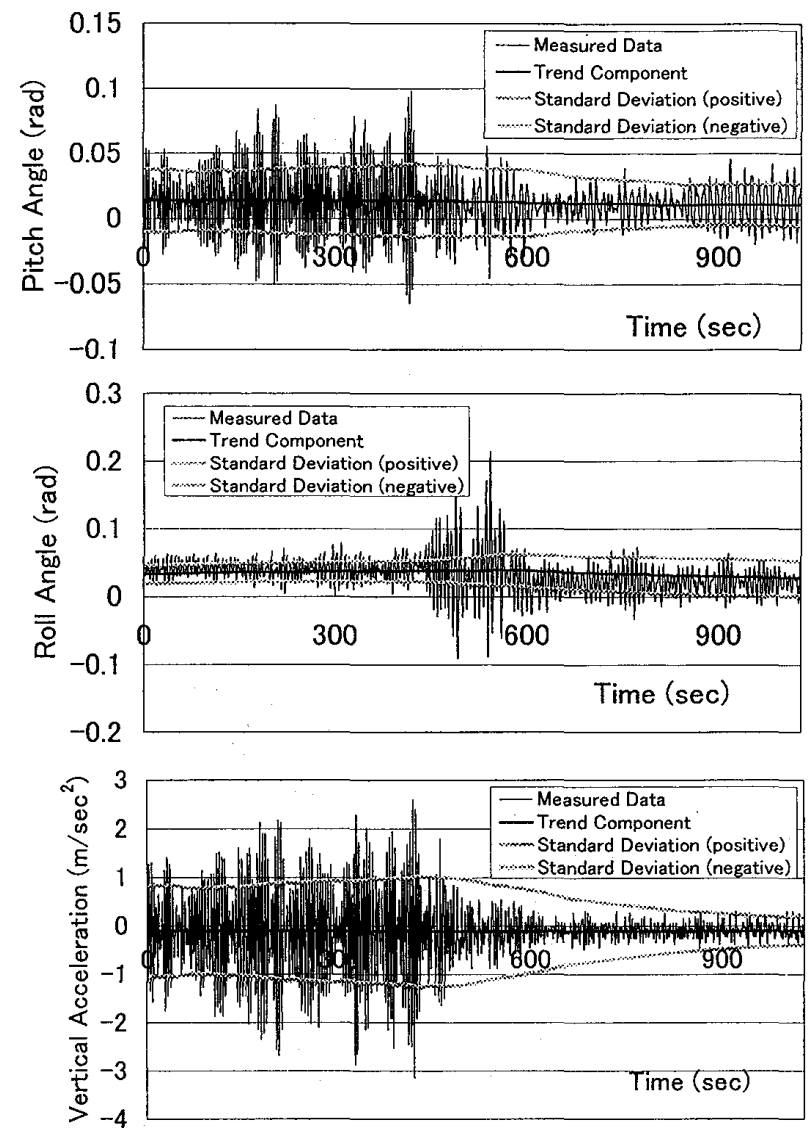

Fig. 4. The typical time histories of the measured data

していることが分かる。波浪外力の影響が顕著に現 れる縦摇れ角㧍よび上下加速度については、向波状 態で航走しているcase1の場合において広い周波数 帯域にスペクトルが存在し、そのパワーも大きいこ とが分かる。そして、変針後の追い波状態で航走し ているcase2の場合では低周波数領域にスペクトル のピークが移動するとともにそのパワーが小さく なっていることが分かり、Fig. 4に示した時系列の 後半部分の動摇抢よび上下加速度が小さい結果と一 致する。これらは、波浪との出会い関係によるスぺ クトル形状の変化の傾向を良く表している。

\section{2 逐次型Bayes法による方向波スペクトルの 推定}

Fig. 6.1(a)からFig. 6.2(b)に、Fig. 5で示した瞬 間クロススペクトルを用いて 5 秒ごとに方向波スぺ クトルを推定した結果の一例について示す。これら の図は、360秒および1030秒の時点における推定結果 を表している。これらの図中の(a) は方向波スペク トルを等高線で示した図であり、奥行き方向に絶詨 周波数、横軸に出会い角 (ITTC座標系)をそれぞれ 表している。(b)は方向波スペクトルを出会い角に ついて積分することにより求めた 1 次元のパワース 


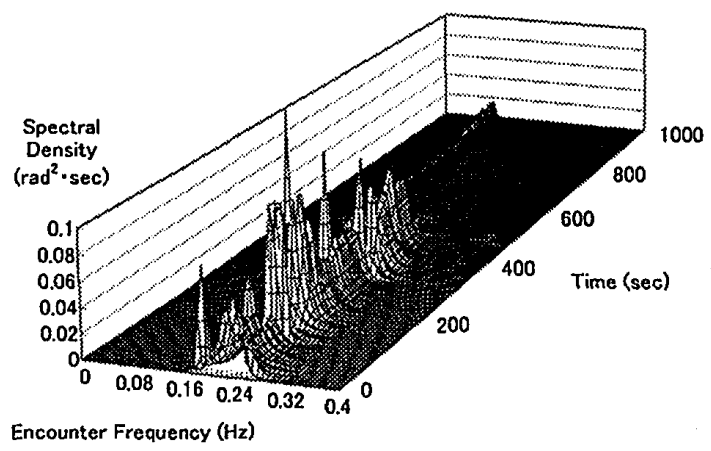

(a) Pitch angle

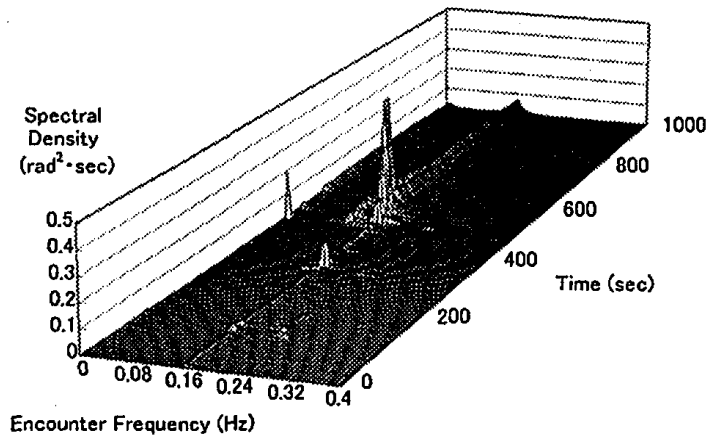

(b) Roll angle

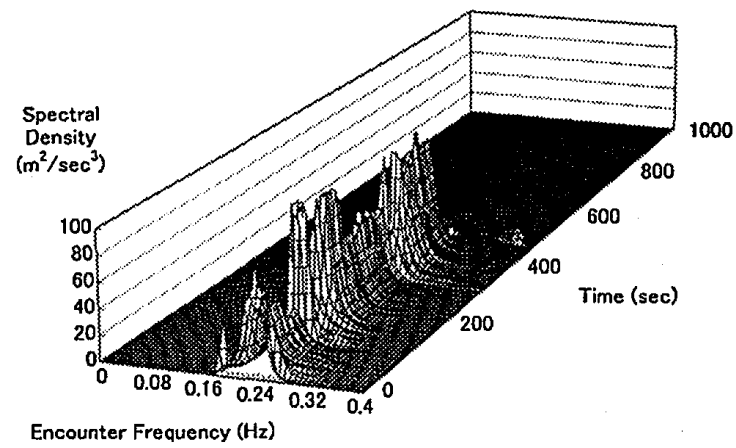

(c) Vertical acceleration

Fig. 5. Instantaneous auto spectra

ペクトルを示した図であり、横軸を絶対周波数とし て縦軸にスペクトル密度を表している。(c) は方向波 スペクトルを周波数について積分することにより求 めた方向分布を示した図であり、横軸を出会い角と して縦軸にスペクトルの方向分布を表している。

推定した方向波スペクトルとTable 1に示した目 視観測による結果とを比較した場合、Fig. 6.1に示 したようにcase1においては、雨者の完全な一致は見 られないがおおむね良好な精度で推定できていると 考えられる。case2の場合においては、有義波高およ び周期については抄扮むね一致していると考えられ るが、波向きに関しては一致しているとは言い難い。 このような結果となった原因としては、case2の場合
において推定しているトレンド、時変分散および瞬 間クロススペクトルの推定誤差の影響が考えられ る。また、今回の推定計算に㧈いては、変針時の船 速を一定として考えて応答関数を推定計算に取り入 れた。そのため、僅かな誤差の蓄積が波向きの推定 值に影響を与えたと考えられる。

一方、本研究においては船体動摇デー夕のみを用 いて推定計算を行うこととした。そのため、推定值 の精度が悪いおよび非定常部分の解析において推定 計算が不安定となるなどの問題点が生じることと なった。しかしながら、前節で導入した新しい制約 条件の効果により、推定計算が安定に行えるように 改善された。さらに、目視観測による有義波高を与 えているので、Fig. 6.1(b)およびFig. 6.2(b)の中に 示したように有義波高に関する推定值は良い結果を 与えていることが確認できる。

\section{6. 結 言}

本研究においては、変針時の非定常性を有する データを含んだ実船動摇デー夕を用い、逐次型 Bayes法を拡張・改良し、実海域の方向波スペクトル を船体動摇デー夕のみから逆推定することを試み た。推定計算の結果と目視観測の結果を比較するこ とにより、次のような知見を得た。

（1）目視観測による有義波高デー夕を推定計算に 直接入力する新しい制約条件式の效果によっ て、船体動摇データのみを用いた推定計算に おいても安定した方向スペクトルが得られ、 かつ方向波スペクトルの積分から求められる 有義波高の推定值と目視観測の結果はよく一 致する。

（2）定常時系列データの前半部分の推定結果につ いては推定值抢よび観測値の結果はよく一致 する。しかしながら、変針後における後半部 分の定常時系列デー夕を用いた解析において は良い一致を示さなかった。この原因として は、トレンド、時変分散および瞬間クロスス ペクトルの推定誤差の影響ならびに変針時の 船速に対応した応答関数を考慮していないこ となどがあげられる。

今後の課題としては、上記(2)に記したように、瞬 閒クロススペクトル解析の信頼性を向上させること およびそのときの船速に対応する船体動摇の応答関 数を自動で取り込めるようにすることなどがあげら れる。 


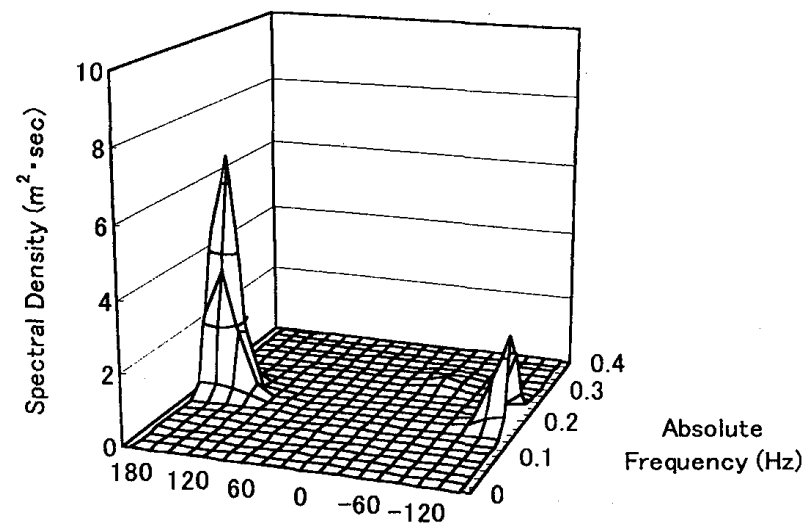

Wave Direction (deg)

(a) Estimated directional wave spectrum

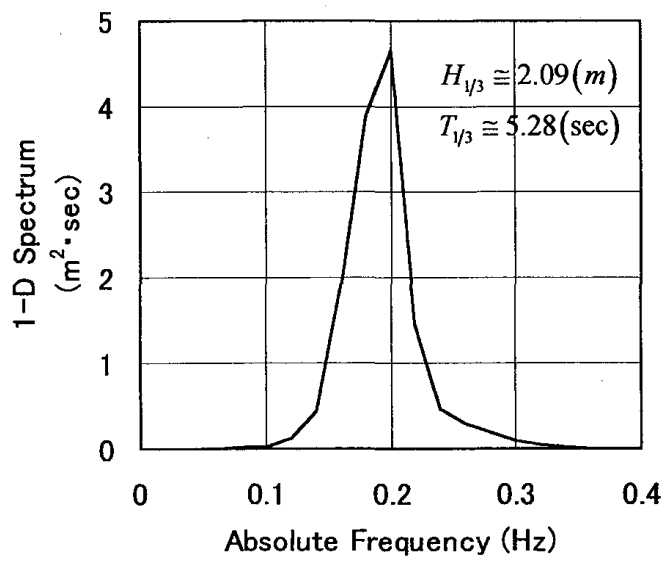

(b) 1-Dimensional spectrum

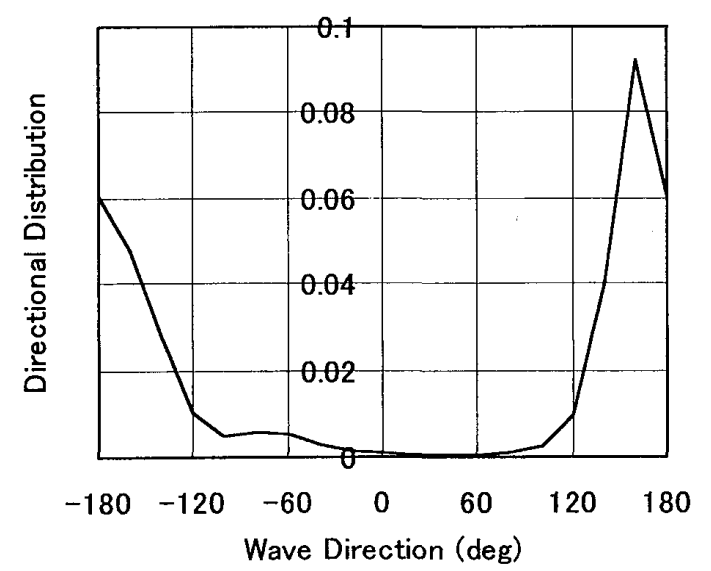

(c) Directional distribution

Fig. 6.1. Example of estimated directional wave spectrum $[360(\mathrm{sec})]$

(a) Estimated directional wave spectrum

(b) 1-Dimensional wave spectrum

(c) Directional distribution

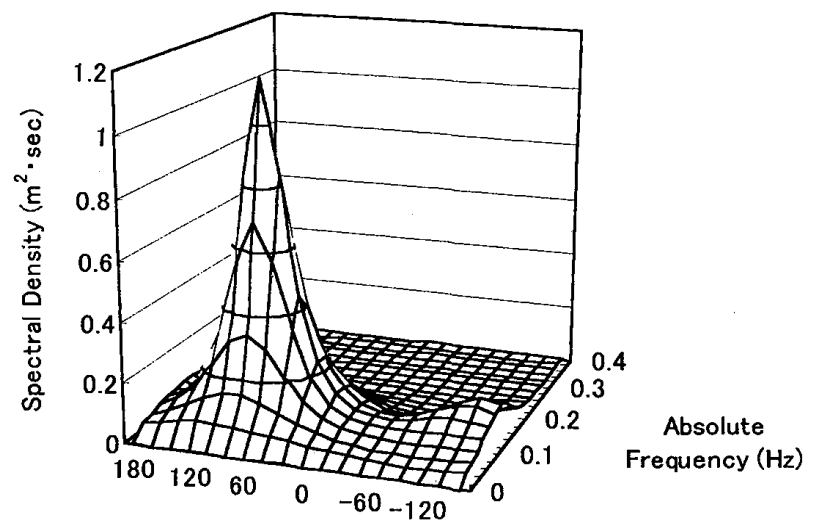

Wave Direction (deg)

(a) Estimated directional wave spectrum

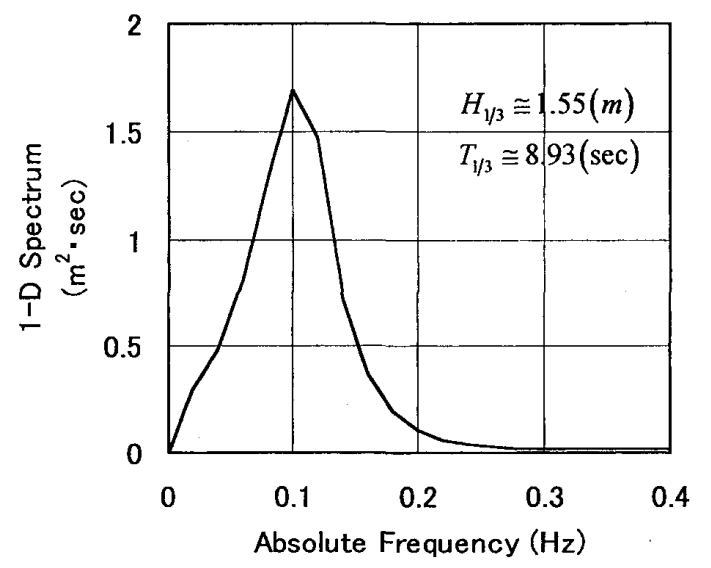

(b) 1-Dimensional spectrum

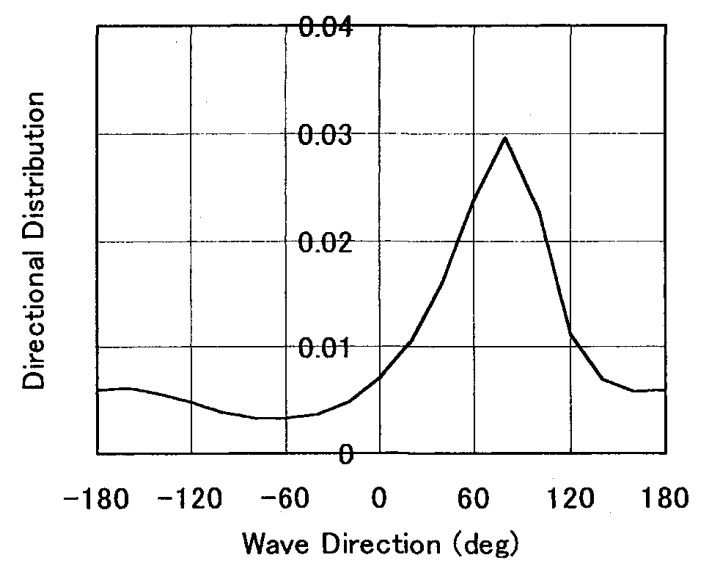

(c) Directional distribution

Fig. 6.2. Example of estimated directional wave spectrum [1030 (sec) ]

(a) Estimated directional wave spectrum

(b) 1-Dimensional wave spectrum

(c) Directional distribution 


\section{謝辞}

実船実験データの採取に際しまして、快く御協力 下さいました東京商船大学付属練習船汐路丸の八田 一郎前船長、覺前修船長ならびに乗組員の方々に心 から感謝の意を表します。

なお、本研究成果の一部は文部科学省科学研究費 補助金 (基盤研究 $C(2))$ ならびに造船学術研究推進機 構の援助によることを付記し、関係各位に深く感謝 いたします。

\section{参 考 文 献}

(1) Iseki, T. and Terada, D. : Bayesian Estimation of Directional Wave Spectra for Ship Guidance System, Transactions of The ISOPE, VOLUME 12, NUMBER 1, pp. 25-30, 2002.

（2）井関俊夫，大津皓平：船体動摇デー夕を用いた 方向波スペクトルのBayes推定 (第 2 報), 日本 造船学会論文集, 第176号，(1994)，pp. 99-105.

（3）井関俊夫：船体波浪計化法による波浪モニタリ ングについて一上下加速度と船載式波高計によ る推定精度の比較一, 日本航海学会論文集, 第 102号，(2000), pp. 107-113.

(4) Jiang, X. Q. and G. Kitagawa : A time varying coefficient vector AR modeling of nonstationary covariance time series, Signal Processing, Vol. 33, No. 3, pp. 315-331, 1993.
（5）井関俊夫，寺田大介：船体応答クロススペクト ルのリアルタイム推定に関する研究，日本造船 学会論文集, 第191号，(2002）, pp. 161-168.

（6）寺田大介，横川智，井関俊夫：船載型船体動摇 解析システムの開発に関する研究一I ., 日本航 海学会論文集，第106号，(2002）, pp. 201-206.

（7）寺田大介, 井関俊夫：方向波スペクトルのオン ライン推定法に関する研究，日本造船学会論文 集 (投稿中), 日本造船学会.

（8）例えば、奥村晴彦：C言語による最新アルゴリ ズム事·典，技術評諭社， 1991 .

\section{質 疑 応 答}

榊原繁樹（横浜ゴム(侏)：推定の安定性のために「推 定有義波高が目視観測結果に一致」の制約条件式 とのことですが、他の部の詳細な計算に較べて少 し粗い感じがするのですが。

寺田大介：御討論ありがとうございます。この制約 条件式を追加した理由としましては、本文中に記 しましたように、時系列データが非定常になる場 合において計算が不安定になる場合が生じたため です。この条件式は、方向波スペクトルを周波数 および出会い角で積分した、いわゆる体積を規定 するものであり、スペクトルの方向分布、周波数 分布に対しては影響を及ばしません。したがいま して、この条件式は安定した数值計算を行うため の妥当な条件式であると考えられます。 